\title{
The GIS approach to evaporite-karst geohazards in Great Britain
}

\author{
A.H. Cooper \\ British Geological Survey, Keyworth, Nottingham, NG12 5GG,UK. \\ e-mail: ahc@bgs.ac.uk
}

\section{COPYRIGHT BGS/NERC}

Published as:

COOPER, A H. 2008. The GIS approach to evaporite karst geohazards in Great Britain. Environmental Geology. Vol 53, 981-992 (also digital publication 2007 DOI 10.1007/s00254-007-0724-8)

\begin{abstract}
Evaporite karst in Great Britain has formed in Permian and Triassic gypsum, and in Triassic salt. Active dissolution of these deposits can occur on a human rather than a geological timescale causing subsidence and building damage. The British Geological Survey has taken two approaches towards understanding and advising on hazards caused by dissolution of these soluble rocks. At a detailed level, a national database and GIS of karstic features is being populated. Information gathered includes dolines, springs, stream sinks, caves and building damage. At a national level, the soluble rocks in Great Britain have been identified and digital-map polygon information relating to them has been extracted from the British 1:50,000-scale digital map. These areas have been assessed, and in places their margins extended to include some overlying rocks where subsidence features are known to penetrate upwards through the overlying sequence. The national areas have then been assessed using the detailed local information to assign a susceptibility rating from A (extremely low) to E (high), depending on the nature and regularity of the subsidence events that occur. This national zonation of the soluble rocks can be used for planning, construction and the insurance businesses. It has also proved useful for assessing the potential stability of linear routes, such as roads and pipelines or for other important structures such as bridges and buildings. The information can also be used to delineate zone of karstic groundwater flow.
\end{abstract}

Keywords: Evaporite; Karst; Subsidence; GIS; Hazard assessment 


\section{Introduction}

Engineering problems, such as subsidence, and irregular rockhead developed over soluble (karstic) rocks, pose difficulties for planning and development and can be very expensive for the construction and insurance industries. At their most extreme they can cause properties to collapse and put lives at risk. The carbonate rocks (mainly limestone and chalk) are well known for their karstic development, however, karst in gypsum and salt are less well known. These rocks dissolve faster and are much more soluble, allowing karst to develop very quickly in these rock types. To understand the problems associated with soluble rocks in Great Britain, the British Geological Survey (BGS) is constructing a database of karst features. This has been utilised in conjunction with digital geological map and scientific information to generate a karst hazard susceptibility map of Great Britain. The map and karst database are important for understanding the severity of the problem and constitute useful tools for hazard avoidance that have relevance to planning, engineering, development and the insurance industry. Developers, planners and the local government can only operate effectively if they know about the hazards that affect them

and have access to suitable geological information. The British Geological Survey is the main national supplier of this geological and geohazard data.

\section{Evaporite karst in Great Britain}

Because evaporite rocks are highly soluble, areas underlain by them in the Great Britain tend to form low ground, which is often extensively covered with superficial deposits. The evaporites are not often seen at outcrop, but can be mapped from borehole data and may be inferred from the sinkholes or dolines that develop across the outcrops and on the overlying strata. The main evaporite deposits at and near outcrop in the Great Britain include Permian gypsum, Triassic gypsum and Triassic salt sequences (Figure 1). They all dissolve to varying degrees depending on the local geological and hydrogeological situation. Gypsum also occurs in some Jurassic rocks in southern Britain, where some evidence of dissolution and tectonic brecciation exists in the form brecciated strata 
known as the Broken Beds (West 1964), but no evidence of modern dissolution or subsidence has been noted.

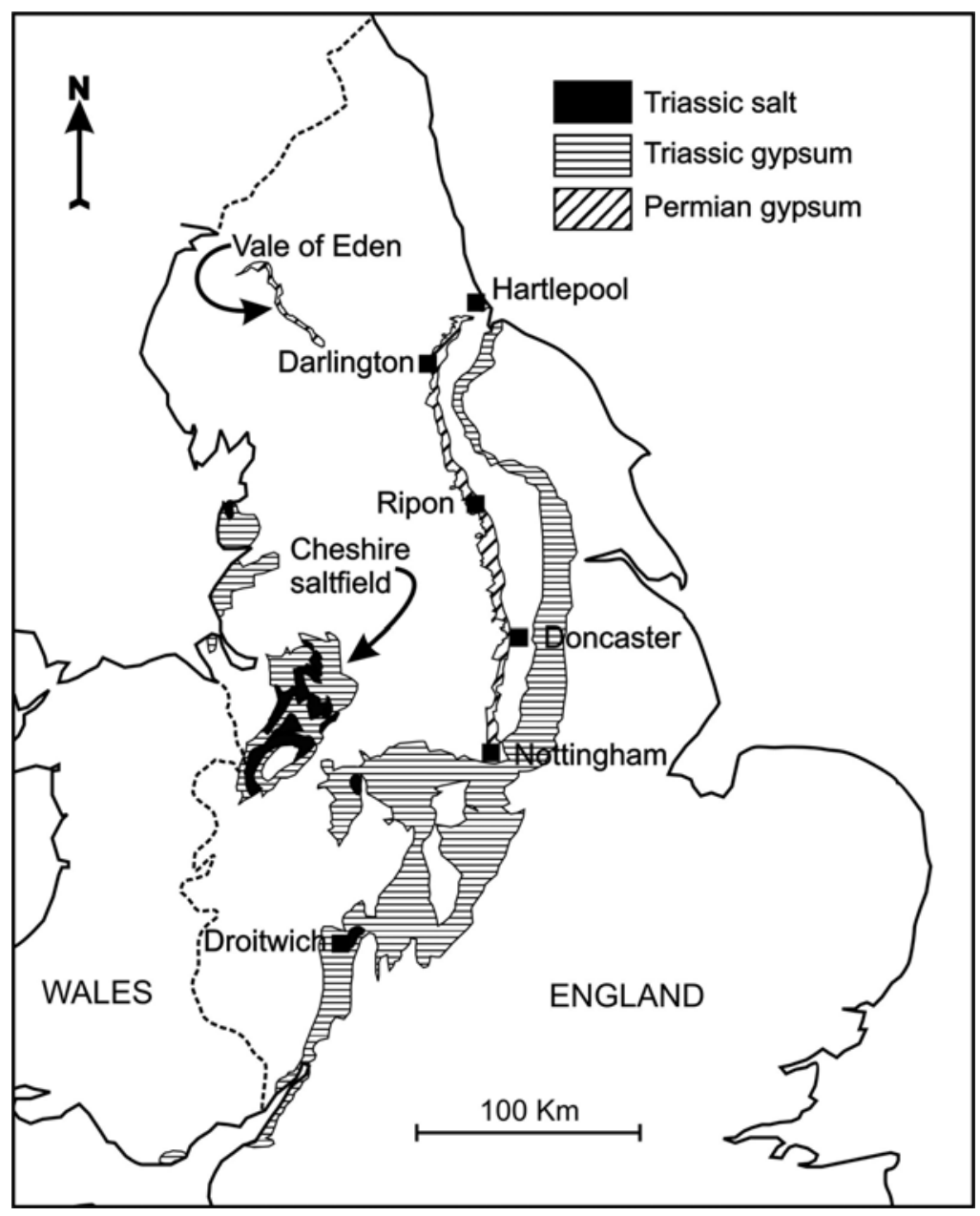

Figure 1. Distribution of the main evaporite karst sequences at outcrop in England

\section{Permian gypsum karst}

In northeast England, karst developed in Permian gypsum occurs in a belt about 3km wide and $100 \mathrm{~km}$ long stretching from just north of Doncaster in the south to Hartlepool in the north. The Permian sequence (Figure 2) comprises two thick units of gypsum underlain by dolomite aquifers. The gypsum is heavily karstified especially in places where the major rivers and buried valleys have cut through the Permian sequence 
producing major pathways for the escape of groundwater from the bedrock into the fluvial system. By comparison with known phreatic gypsum cave systems (such as those in the Ukraine, Klimchouk et al 1997) and from the pattern of subsidence, it is inferred that there are phreatic cave systems in the gypsum caused by the allogenic recharge from the adjacent ground, particularly the dip slopes of the dolomite aquifers and the overlying sandstone aquifer, into major the valleys. The rapid solubility rate of the gypsum means that the karst is evolving on a human time scale and active subsidence occurs in many places, especially around the town of Ripon (Cooper 1986, 1989, 1998). The active nature of the dissolution and the ongoing subsidence features here cause difficult ground conditions for planning and development (Thompson et al 1996, Paukstys et al 1997, Cooper 1998) and for road and bridge construction (Cooper and Saunders 2002, Jones and Cooper 2005). In this area water abstraction can aggravate the problem and lead to enhanced dissolution and collapse (Cooper 1988). Gypsum karst is also present in the Permian rocks of the Vale of Eden (Ryder and Cooper 1993), but here it is less extensive as the gypsum is sandwiched within a mudstone sequence, which restricts the passage of water through the gypsum.

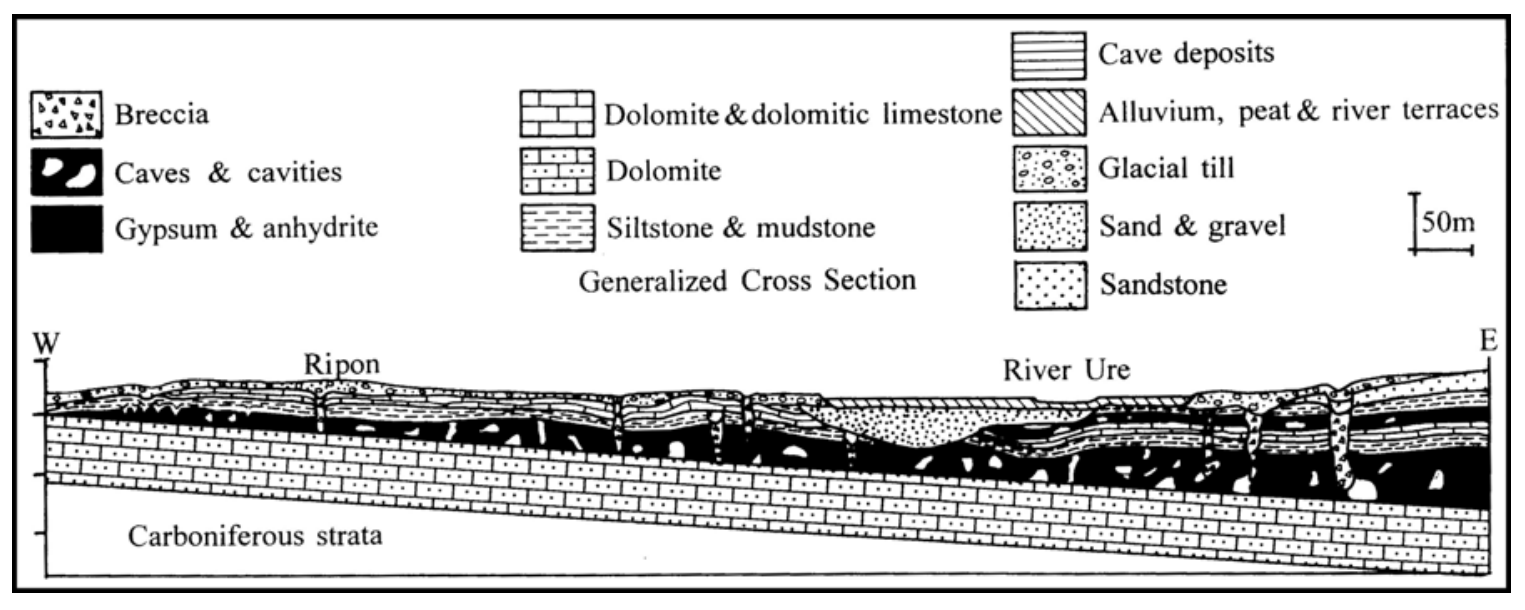

Figure 2. Cross-section through the typical Permian gypsum sequence at Ripon, North Yorkshire. The Dolomite at the base of the sequence is the Cadeby Formation, which is overlain by gypsum and mudstone of the Edlington Formation, dolomite and dolomitic limestone of the Brotherton Formation, gypsum and mudstone of the Roxby Formation. The Permian sequence is capped by the arenaceous Sherwood Sandstone Group of 
Triassic age. The sequence is cut into by the buried valley of the River Ure and perforated by breccia pipes caused by collapse following gypsum dissolution.

\section{Triassic gypsum karst}

Gypsum karst is present in the Triassic strata, but the effects of it are much less severe than those in the Permian rocks. The difference is mainly caused by the thickness of Triassic gypsum (typically less than $5 \mathrm{~m}$ ) and the fact it is interbedded with mainly weakly permeable mudstone sequences (Figure 3). In places subsidence does occur with sinkholes largely triggered by the infiltration of surface water carrying down fine material into subsurface cavities. Leakage of water from installations such as power generation stations has been recorded to have aggravated dissolution and caused subsidence (Seedhouse and Sanders 1993). The presence of gypsum karst has also produced difficult ground conditions for road construction south of Derby (Cooper and Saunders 2002).

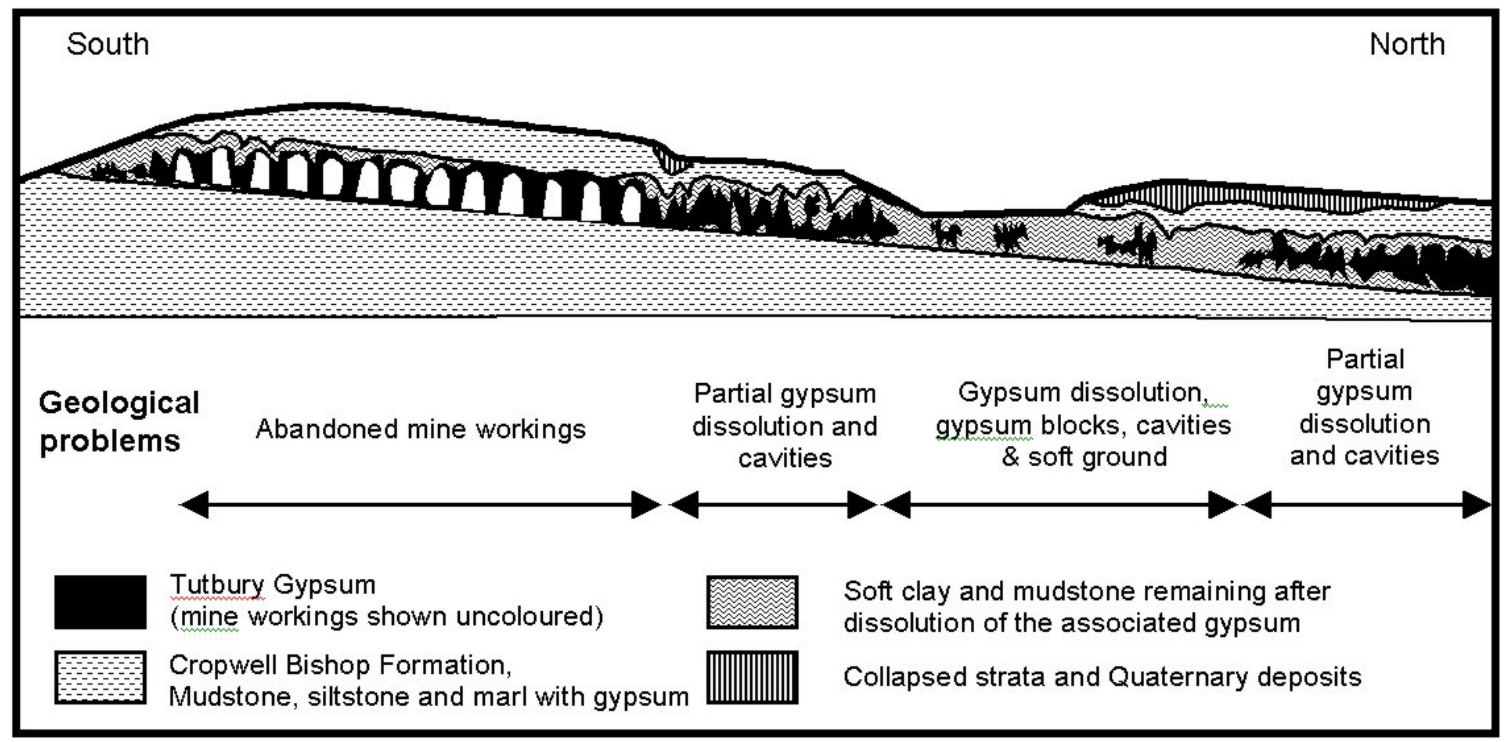

Figure 3. Cross-section through Triassic gypsiferous strata of the Cropwell Bishop Formation (Mercia Mudstone Group) south of Derby. The gypsum caps the hill and is slightly dissolved capping in the south where it has also been mined. To the north there is 
a zone of greater dissolution, approximately at the present water table and down-dip from this the amount of dissolution decreases and the amount of gypsum increases.

\section{Triassic salt karst}

Salt near surface in Great Britain occurs mainly in the Triassic strata of central and northwestern England. The towns on the Triassic salt strata commonly have "wich" or "wych" in their names, a term derived from the old English word for a salt spring. These names indicate that the towns are sited on former salt springs, which emanated from the actively dissolving salt karst (Cooper 2002). Starting with the exploitation of natural brine, these saline spring sites later became the focus for shallow mining and near-surface brine extraction (Figure 4). The method used was to sink wells or drill boreholes to intersect the near surface "brine runs" a technique that was called "wild" brine extraction and which exacerbated the salt karstification (Arup Geotechnics 1991, Calvert 1915, Collins 1971). The exploitation of "wild" brine has resulted in near-linear belts of subsidence trending towards the abstraction point and partly controlled by the geological structure. Most extraction of natural brine has ceased and modern exploitation is mainly in dry mines or by deep controlled brine extraction leaving brine-filled cavities. Since the cessation of natural brine pumping, the saline ground water levels have returned towards their pre-pumping state. Brine springs are becoming re-established and natural karstification and subsidence may be expected to occur though heavily influenced by the man-made brine runs. 


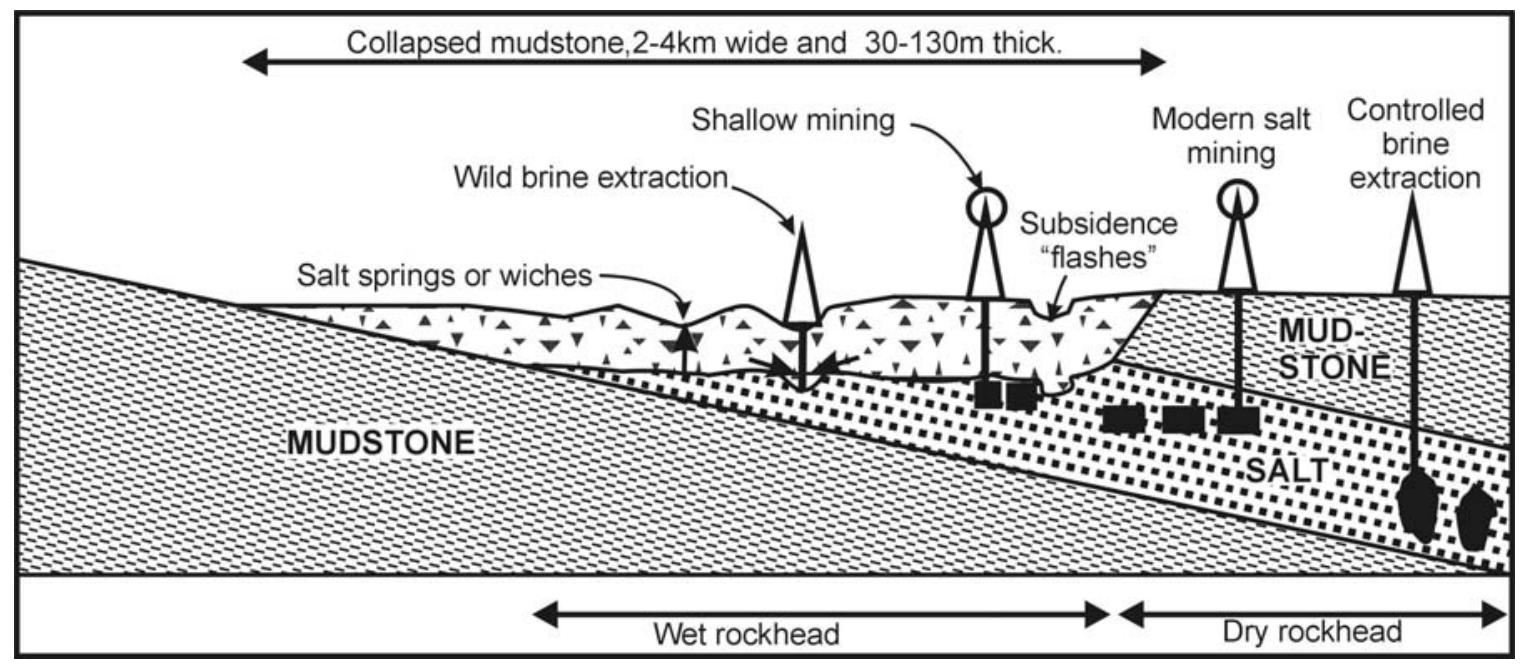

Figure 4. Cross-section though Triassic salt deposits in Cheshire. At wet rockhead there is a zone of intense dissolution and collapse where the salt is overlain by brecciated and collapsed strata.

\section{The karst database and GIS}

It has been recognised for some time that the availability of baseline data is essential for the assessment of geological hazards. Guidance for the development on unstable land is written into British Government planning policy in the "Planning policy guidance note 14: Development on unstable land” (Department of the Environment 1990), and the supplementary “Annex 2” (Department of Transport, Local Government and the Regions 2002). To underpin this policy, rudimentary baseline data was collected in an initial database of natural cavities commissioned by the Department of the Environment and produced by Applied Geology Ltd (1993). This study showed the national distribution of karst and other natural cavities, but did not include all the detail that was available and some of the spatial recording was not very accurate. Consequently, in 2000, the British Geological Survey embarked on constructing a more comprehensive Geographic Information System (GIS) and database of karst information (Cooper et al 2001). Over the past 6 years this system has been populated and karst features for most of the evaporite areas have been added; in addition, about one quarter of the limestone and half of the chalk karst in the country has been included in the database. 
Information gathered during fieldwork is either recorded digitally on portable tablet computers or on proforma field data sheets that have the same data fields as the GIS and its underlying database. Data is gathered either in the field or from existing datasets such as scanned and georegistered copies of the geologists field maps, historical and modern georegistered Ordnance Survey maps, papers and historical documents. The information is added directly into the GIS and five categories of data are collected: dolines or sinkholes, springs, stream sinks, caves and building damage.

The data is entered into the GIS using the British Geological Survey desktop data capture methodology, the “Geological Spatial Database” (GSD) system, developed by Keith Adlam; initially using ArcView3 (Cooper et al 2001), this system has now been migrated to ArcGIS9. The data is stored in ArcGIS format on central servers, but the point information and database tables are also copied to centralised Oracle databases to allow compatibility with the main BGS datasets. In common with all BGS databases, the information added to the system has common header data including National Grid coordinates, date entered, user ID and reliability (this is not shown on tables 1-5 below).

For dolines and sinkholes, the data can be gathered either as a point for a small collapse, or depending on the scale as a polygon for more extensive areas. Once a point or polygon is captured, the GSD presents a drop down list of information to be populated. The details gathered are shown in tables 1 (Dolines or sinkholes), 2 (springs), 3 (stream sinks), 4 (caves) and 5 (building damage) listed below. The size of springs and stream sinks are recorded, but it is generally subjective and weather dependent on the time of year and recent rainfall. Furthermore, for the majority of historical information gathered from published maps and geologist field maps, no precise description of spring or stream sink flow is given. Information gathered for caves is also collected as either point data for cave entrances, or if it is known, as linear data for the approximate centre lines of the caves themselves. The functionality is there in the software to include full cave plans, but commonly these have copyright restrictions and cannot be included. Many of the doline 
and sinkhole affected areas also suffer from building damage and damage to

infrastructure.

\begin{tabular}{|l|l|}
\hline Sinkholes: record item & Parameters \\
\hline Sinkhole Name & Free text \\
\hline Size & Size x, Size y, Size z, metres. \\
\hline Type & Compound, collapse, suffusion, solution, no data, buried \\
\hline Shape & Round, oval, irregular, modified, compound, no data. \\
\hline Surface profile & Pipe, cone, inverted cone, saucer, complex, levelled (filled), no data \\
\hline Infill deposits & $\begin{array}{l}\text { British Geological Survey rock and stratigraphical codes with } \\
\text { thicknesses }\end{array}$ \\
\hline Subsidence type & Gradual, episodic, instantaneous, no data \\
\hline Evidence of quarrying & Yes, no, no data. \\
\hline Primary data source & $\begin{array}{l}\text { Field mapping, air-photo, site-investigation, database, maps and } \\
\text { surveys, literature, Lidar remote sensing, DoE database, no data. }\end{array}$ \\
\hline Reliability & Good, probable, poor, no data \\
\hline Property damage & Yes, no, no data \\
\hline Oldest recorded subsidence & dd/mm/yyyy \\
\hline Intermediate subsidence events & dd/mm/yyyy \\
\hline Most recent subsidence & dd/mm/yyyy \\
\hline Other data & Free text \\
\hline References & Free text \\
\hline
\end{tabular}

Table 1 datafields gathered for dolines or sinkholes.

\begin{tabular}{|l|l|}
\hline Springs; record item & Parameters \\
\hline Spring name & Free text \\
\hline Elevation & Metres \\
\hline Situation & $\begin{array}{l}\text { Open surface, borehole, concealed, submerged, submarine, } \\
\text { underground inlet, no data }\end{array}$ \\
\hline Proven dye trace & Yes, no \\
\hline Flow & $\begin{array}{l}\text { Ephemeral, fluctuating, constant, flood overflow, ebbing \& flowing, } \\
\text { no data }\end{array}$ \\
\hline Water type & Normal/fresh, saline, sulphate, tufaceous, other mineral, no data \\
\hline Size & $\begin{array}{l}\text { Trickle, small stream, medium stream, large stream, small river, } \\
\text { medium river, large river, no data }\end{array}$ \\
\hline Primary data source & $\begin{array}{l}\text { Field mapping, air-photo, site-investigation, database, maps and } \\
\text { surveys, literature, Lidar remote sensing, DoE database, no data. }\end{array}$ \\
\hline Artesian & Yes, no, no data \\
\hline Thermal & Yes, no, no data \\
\hline Karstic & Yes, no, no data \\
\hline Uses & None, public, agricultural, industrial, other, no data. \\
\hline Character & Single discrete, multiple discrete, diffuse, no data \\
\hline Reliability & Good, probable, poor, no data \\
\hline Estimated discharge & Litres per second (ls ${ }^{-1}$ ) \\
\hline Other data & Free text \\
\hline References & Free text \\
\hline
\end{tabular}

Table 2 datafields gathered for springs 


\begin{tabular}{|l|l|}
\hline Stream sinks; record item & Parameters \\
\hline Sink name & Free text \\
\hline Elevation & Metres \\
\hline Proven dye traces & Yes, no, no data \\
\hline Morphology & $\begin{array}{l}\text { Discrete compound, discrete single sink, diffuse sink, losing stream, } \\
\text { ponded sink, cave entrance, concealed sink, no data }\end{array}$ \\
\hline Flow & Perennial, intermittent, ephemeral (flood), Estavelle, no data \\
\hline Size & $\begin{array}{l}\text { Trickle, small stream, medium stream, large stream, small river, } \\
\text { medium river, large river, no data }\end{array}$ \\
\hline Primary data source & $\begin{array}{l}\text { Field mapping, air-photo, site-investigation, database, maps and } \\
\text { surveys, literature, Lidar remote sensing, DoE database, no data }\end{array}$ \\
\hline Reliability & Good, probable, poor, no data \\
\hline Estimated discharge & Litres per second (ls ${ }^{-1}$ ) \\
\hline Other data & Free text \\
\hline References & Free text \\
\hline
\end{tabular}

Table 3 datafields gathered for stream sinks

\begin{tabular}{|l|l|}
\hline Natural cavities, record item & Parameters \\
\hline Cavity name & Free text \\
\hline Length & Metres \\
\hline Vertical range & Metres \\
\hline Elevation & Metres \\
\hline Type & $\begin{array}{l}\text { Open cave natural, infilled cave natural, gull cave, lava tube, } \\
\text { boulder, peat cave, sea cave, stoping cavity, palaeokarst, } \\
\text { hydrothermal, borehole cavity, no data. }\end{array}$ \\
\hline $\begin{array}{l}\text { Rock units penetrated (solid and } \\
\text { drift) }\end{array}$ & British Geological Survey rock and stratigraphical codes \\
\hline Primary data source & $\begin{array}{l}\text { Field mapping, air-photo, site-investigation, database, maps and } \\
\text { surveys, literature, Lidar remote sensing, DoE database, no data }\end{array}$ \\
\hline Streamway & Yes, no, no data \\
\hline Other entrance & Yes, no, no data \\
\hline Evidence of mining & Yes, no, no data \\
\hline Reliability & Good, probable, poor, no data \\
\hline Other data & Free text \\
\hline References & Free text \\
\hline
\end{tabular}

\section{Table 4 datafields gathered for natural cavities}

\begin{tabular}{|l|l|}
\hline Property damage, record item & Parameters \\
\hline Address & Free text \\
\hline Postcode & Postcode format \\
\hline Elevation & Metres \\
\hline Damage survey 1 & Date (dd/mm/yyyy), notes, Damage rating (1-7) \\
\hline Damage survey 2 & Date (dd/mm/yyyy), notes, Damage rating (1-7) \\
\hline Damage survey 3 & Date (dd/mm/yyyy), notes, Damage rating (1-7) \\
\hline Suspected cause & $\begin{array}{l}\text { Natural subsidence, mining subsidence, landslip, compressible fill, } \\
\text { building defect }\end{array}$ \\
\hline Reliability & Good, probable, poor, no data \\
\hline Other data & Free text \\
\hline References & Free text \\
\hline
\end{tabular}

\footnotetext{
Table 5 datafields gathered for property damage
} 
The GIS allows building damage to be recorded and has the functionality to allow this to be done on one, two or three occasions allowing multi-temporal analysis of the data. The proforma and GIS allow information on suspected cause and reliability to be included.

The methodology and dataset is also applicable to mining and landslip subsidence and the recording scheme has been designed to cope with information from those sources. The building damage classification has 7 classes. The first 5 classes are based on the National Coal Board (NCB 1975) Subsidence Engineers Handbook classification. This has been extended to include partial collapse (Category 6) and total collapse (Category 7). In addition to damage to buildings, the scheme has information relevant to the recording of damage to roads, pavements and land (Table 6). The recording of building damage using the original 5 categories of the NCB scheme has been successfully applied to Ripon in Great Britain (Griffin 1986, McNeary 2000) and to Calatayud in Spain (Gutierrez and Cooper 2002). 


\begin{tabular}{|c|c|c|}
\hline $\begin{array}{l}\text { Damage } \\
\text { Category }\end{array}$ & Description of typical building damage & $\begin{array}{l}\text { Description of associated damage to } \\
\text { roads and land }\end{array}$ \\
\hline 0 & $\begin{array}{l}\text { Hairline cracking, widths to } 0.1 \mathrm{~mm} \text {. Not visible from } \\
\text { outside }\end{array}$ & Not visible \\
\hline 1 & $\begin{array}{l}\text { Fine cracks, generally restricted to internal wall } \\
\text { finishes; cracks rarely visible in external brickwork. } \\
\text { Typical crack widths up to } 1 \mathrm{~mm} \text {. Generally not } \\
\text { visible from outside. }\end{array}$ & Not visible \\
\hline 2 & $\begin{array}{l}\text { Cracks not necessarily visible externally, some } \\
\text { external repointing may be required. Doors and } \\
\text { windows may stick slightly, typical crack widths up } \\
\text { to } 5 \mathrm{~mm} \text {. Difficult to record from outside. }\end{array}$ & Generally not visible \\
\hline 3 & $\begin{array}{l}\text { Cracks which can be patched by a builder. } \\
\text { Repointing of external brickwork and possibly a } \\
\text { small amount of brickwork to be replaced. Doors and } \\
\text { windows sticking, slight tilts to walls, service pipes } \\
\text { may fracture. Typical crack widths are } 5 \text { to } 15 \mathrm{~mm} \text { or } \\
\text { several of say 3mm. Visible from the outside. }\end{array}$ & $\begin{array}{l}\text { Slight depression in open ground or } \\
\text { highway, noticeable to vehicle users, } \\
\text { but may not be obvious to casual } \\
\text { observers. Repairs generally } \\
\text { superficial, but may involve limited } \\
\text { local pavement reconstruction. }\end{array}$ \\
\hline 4 & $\begin{array}{l}\text { Extensive damage that requires breaking-out and } \\
\text { replacing including sections of walls and especially } \\
\text { over doors and windows. Windows and door frames } \\
\text { distorted, floors sloping noticeably. Walls leaning or } \\
\text { bulging noticeably; some loss of bearing of beams, } \\
\text { some distortion of structure. Service pipes disrupted. } \\
\text { Typical crack widths } 15 \text { to } 25 \mathrm{~mm} \text {, but depends on } \\
\text { number of cracks. Noticeable from outside. }\end{array}$ & $\begin{array}{l}\text { Significant depressions, often } \\
\text { accompanied by cracking in open } \\
\text { ground or highway. Obvious to the } \\
\text { casual observer. Small open hole may } \\
\text { form. Repairs to the highway generally } \\
\text { require excavation and reconstruction } \\
\text { of the road pavement. }\end{array}$ \\
\hline 5 & $\begin{array}{l}\text { Structural damage which requires a major repair job, } \\
\text { involving partial or complete rebuilding. Beams } \\
\text { loose, bearing walls lean badly and require shoring. } \\
\text { Windows broken with distortion. Danger of } \\
\text { instability. Typical crack widths are greater than } \\
25 \mathrm{~mm} \text {, but it depends on the number of cracks. Very } \\
\text { obvious from outside. }\end{array}$ & $\begin{array}{l}\text { Rotation or slewing of the ground or } \\
\text { significant depression, often } \\
\text { accompanied by cracking. In open } \\
\text { ground or highway; open crater formed } \\
\text { with large void. General disruption of } \\
\text { services in highways. Significant repair } \\
\text { required. }\end{array}$ \\
\hline 6 & Partial collapse. & $\begin{array}{l}\text { Collapse of ground or highway, } \\
\text { significant open void, services severed } \\
\text { or severely disrupted. }\end{array}$ \\
\hline 7 & Total collapse. & Large open void or landslip scar. \\
\hline
\end{tabular}

Table 6. Classification of building damage for karst and other subsidence recording.

To understand the karst of Great Britain and make a dataset that can be used the assessment of karst geohazards, the British Geological Survey has utilised this detailed karst information to constrain the GeoSure dissolution dataset. 


\section{The GeoSure dissolution dataset}

Over the past decade, the British Geological Survey has invested a considerable amount of resources in the production of digital geological map data for the UK. Digital geological maps are available for most of the country (except for a small part of Wales) at a scale of 1:50,000 with all the country covered at the 1:250,000 and 1:625,000 scales; in addition, a significant amount of the country is now digitised at the 1:10,000 scale. All these datasets include the bedrock and the 625,000, 50,000 and 10,000 scale datasets also include data for the superficial deposits. 1:50,000 and 1:10,000 scale digital data is also available for artificial deposits and mass movement (mainly landslip) deposits. The coverage of digital data is listed on the Internet on the BGS Internet GIS search http://www.bgs.ac.uk/geoindex/index.htm under the theme of "Map products" and the category of "Digital geological maps 50,000" which becomes active when zoomed in. Other information about the digital map datasets is accessed from the page: http://www.bgs.ac.uk/products/digitalmaps/digmapgb.html.

In the digital geological map dataset, every polygon of digital geological data is attributed with a two-part seed (LEX-ROCK) that gives its lithostratigraphy and its lithology. All the lithostratigraphical (LEX) codes are listed on the Internet at http://www.bgs.ac.uk/lexicon/lexicon_intro.html where they can be actively searched by name or code; many of the entries include extended information describing the units and their type localities. The lithological codes (ROCK) are also explained and listed on the Internet at http://www.bgs.ac.uk/bgsrcs/home.html and can be searched by name or code at http://www.bgs.ac.uk/bgsrcs/searchrcs.html. The 1:50,000 scale digital geological map dataset is now being developed in its third edition.

The availability of digital map data linked to GIS software has opened new doors for the interrogation and utilisation of geological data in the UK. The British Geological Survey has produced new digital products for geological hazards, which it markets under the name of GeoSure (http://www.bgs.ac.uk/products/geosure/home.html). Several derived datasets have been produced using a variety of algorithms to provide geohazard data for 
soluble rocks (dissolution); landslides (slope instability); compressible ground;

collapsible rocks; shrink swell; and running sand. The methodology that underlies the construction of the dissolution dataset is described here.

\section{Identification of the evaporite and overlying collapse-affected formations}

The first step in generating the soluble rock geohazard layer in the GeoSure dataset was to identify all the rocks in Great Britain, which contain a significant amount of evaporites and which are susceptible to dissolution and sinkhole development. Basically these are all the formations that included a substantial amount of gypsum and salt at or near outcrop. These were obtained from the digital 1:50,000 scale bedrock data, supplemented in a few places by 1:250,000 scale data. A search of all the lithological codes for evaporite rocks attached to the digital geological map polygons generated the first listing. Secondly a similar search was done of any formations and groups that were known to include evaporite rocks, but where they are a lesser constituent and thus not shown by the main lithological code. These selections were then displayed in the GIS (Figure 5, A) and compared with the known distribution of karstic features from both the Department of the Environment Natural Cavities Database (Applied Geology Limited 1993) and the BGS karst database (Figure 5, B).

\section{Identification of marginal areas}

From the superimposition of the map polygon information with the karst database information (Figure 5, B) and by incorporating previous local knowledge (Figure 5, C) it was possible to pinpoint any interstratal karst. It was also possible to identify several formations that are not karstic themselves, but which are affected by karstic subsidence emanating from the underlying evaporite sequences. For example in the Ripon area, the Permian sequence from bottom to top comprises dolomite of the Cadeby Formation, gypsum and mudstone of the Edlington Formation, dolomite of the Brotherton Formation

and gypsum and mudstone of the Roxby Formation. The sequence dips gently eastwards (Figure 2) and is capped by the Triassic Sherwood Sandstone Group. The Edlington and 
Roxby formations include significant thicknesses of gypsum (up to $40 \mathrm{~m}$ and $10 \mathrm{~m}$ thick respectively), but the Brotherton Formation and the lower part of the Sherwood Sandstone Group are also both affected by severe subsidence due to the dissolution of the underlying gypsum. The whole of the Brotherton Formation can be affected by subsidence emanating from gypsum dissolution, but only the western part (from a few $100 \mathrm{~m}$ to a Km or so) of the Sherwood Sandstone is affected. Although both the Cadeby and Brotherton Formations are dolomite, they are only slightly affected by karstification of this rock.

To utilise this knowledge and to generate the GeoSure dissolution dataset for the Permian rocks in north-east England, it was necessary to combine the polygons for the Edlington Formation, the Brotherton Formation, the Roxby Formation and the part of the Sherwood Sandstone Group that was affected. This generated a merged (Figure 5, D) polygon for all the rock that was susceptible to subsidence, but it gave no indication of the severity of the collapses that have occurred or may occur in that area. 

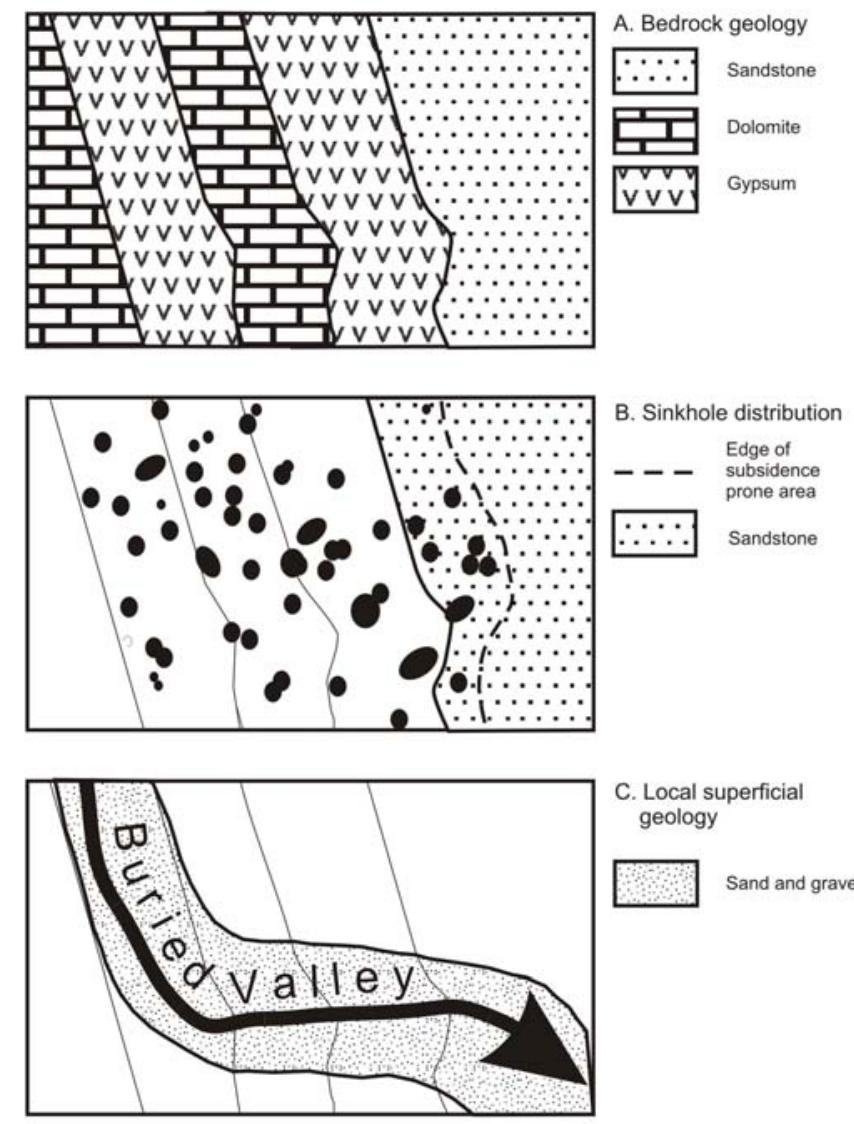

C. Local superficial geology

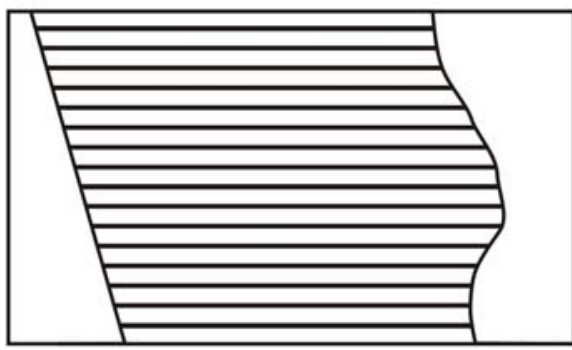

D. Subsidence suseptible zone

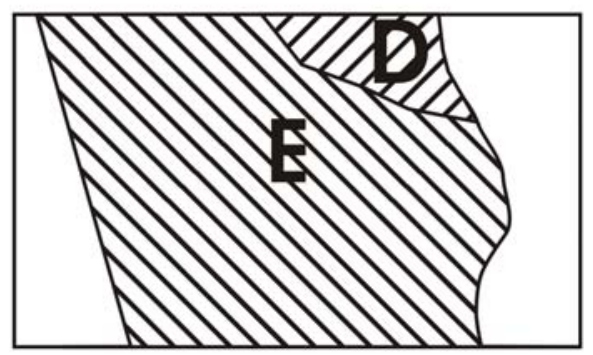

\section{E. Subdivisions} of subsidence suseptible zone

Figure 5 (a-e) These figures show the way the national dissolution dataset is built from digital map data and the karst database information combined with local geological knowledge to construct the national zonation detailing the dissolution susceptibility for gypsum and salt 


\section{Zonation of the karst-collapse prone areas}

Using the detailed BGS karst database and the National Cavities Database (Applied Geology Ltd 1993) the severity of the dissolution hazards were assessed and related to the local bedrock and superficial geology. This allowed the subsidence prone areas with good information to be geologically characterised and zoned (Figure 5, D). This assessment was then used to generate the rankings (Tables 7 and 8), which relate to the degree to which future problems may locally occur. The extension of this ranking into areas where the database of subsidence events is patchy (due to variability in the information) is slightly subjective, but it does allow national geohazard coverage based on the geological parameters to be generated. The five-fold subdivision is used and this is an internal British Geological Survey standard for assessing geological hazards; similar ratings of severity have been applied to landslips, compressible ground, collapsible ground, running sand and shrink-swell clays. For gypsum, five subdivisions were compiled with Ripon in North Yorkshire taken as the worst-case scenario and areas where soluble rocks exist, but where there is little or no known subsidence has occurred taken as the least severe case; for the gypsum sequences the zonation is:

\begin{tabular}{|l|l|}
\hline Ranking & Details \\
\hline $\begin{array}{l}\text { A - } \\
\text { Extremely } \\
\text { low }\end{array}$ & $\begin{array}{l}\text { Areas where gypsum is present, but the thickness of deposits is known to be thin, where } \\
\text { the adjacent rocks are not aquifers and there is no recorded subsidence. Mainly the } \\
\text { Triassic Mercia Mudstone Group where fibrous gypsum has been recorded. }\end{array}$ \\
\hline $\begin{array}{l}\text { B - } \\
\text { Very low }\end{array}$ & $\begin{array}{l}\text { Areas where gypsum is present in substantial thicknesses, but where the adjacent rocks are } \\
\text { not aquifers and where there is no recorded subsidence. Mainly the Triassic Mercia } \\
\text { Mudstone Group where thick gypsum is present. }\end{array}$ \\
\hline C - & $\begin{array}{l}\text { Areas where gypsum is present in substantial thicknesses, where the adjacent rocks may or } \\
\text { may not be aquifers, but where there is no recorded subsidence. Mainly the Triassic } \\
\text { Mercia Mudstone Group where thick gypsum is present and some karstification has } \\
\text { occurred. Similarly, the majority of the Permian gypsum in the Vale of Eden and some of } \\
\text { the Permian gypsum of eastern England are also included. }\end{array}$ \\
\hline $\begin{array}{l}\text { D- } \\
\text { Moderate }\end{array}$ & $\begin{array}{l}\text { Areas where gypsum is present in substantial thicknesses, where the adjacent rocks are } \\
\text { aquifers and where there is some recorded subsidence. Mainly the Permian gypsum of } \\
\text { eastern England, including areas peripheral to Ripon, Darlington, Tadcaster, Church } \\
\text { Fenton etc. }\end{array}$ \\
\hline $\begin{array}{l}\text { E- } \\
\text { High }\end{array}$ & $\begin{array}{l}\text { Areas where gypsum is present in substantial thicknesses, where the adjacent rocks are } \\
\text { aquifers, where buried valleys cut through the sequence and where there are numerous } \\
\text { records of ongoing subsidence. Mainly the Permian gypsum of eastern England including } \\
\text { south of Darlington, Ripon, and near Brotherton. }\end{array}$ \\
\hline
\end{tabular}

Table 7, parameters used to define the hazard ranking for gypsum dissolution prone areas. 
The geological parameters for the salt sequences are different, but generate the same categories with subsidence geohazards rankings comparable to those used for the gypsum sequences:

\begin{tabular}{|l|l|}
\hline Ranking & Details \\
\hline $\begin{array}{l}\text { A- } \\
\text { Extremely }\end{array}$ & $\begin{array}{l}\text { Areas where salt is present, but the thickness of deposits is known to be thin and covered } \\
\text { with impervious material }\end{array}$ \\
\hline $\begin{array}{l}\text { B - } \\
\text { Very low }\end{array}$ & $\begin{array}{l}\text { Areas where salt is present in substantial thicknesses, but where the deposits are covered } \\
\text { with impervious material. }\end{array}$ \\
\hline $\begin{array}{l}\text { C - } \\
\text { Low }\end{array}$ & $\begin{array}{l}\text { Areas where salt is present in substantial thicknesses and present at rockhead (wet } \\
\text { rockhead). }\end{array}$ \\
\hline $\begin{array}{l}\text { D- } \\
\text { Moderate }\end{array}$ & $\begin{array}{l}\text { Areas where salt is present in substantial thicknesses, present at rockhead (wet rockhead) } \\
\text { and where salt springs are present in the area. }\end{array}$ \\
\hline $\begin{array}{l}\text { E- } \\
\text { High }\end{array}$ & $\begin{array}{l}\text { Areas where salt is present in substantial thicknesses, present at rockhead (wet rockhead) } \\
\text { and where wild brining or nearby mining has occurred, salt springs are present and there is } \\
\text { some recorded subsidence in the vicinity; mainly the Triassic salt of Cheshire and } \\
\text { Worcestershire. }\end{array}$ \\
\hline
\end{tabular}

Table 8, parameters used to define the hazard ranking for salt dissolution prone areas.

Although the datasets have been subdivided into five categories, the extremely low (A) and very low categories (B) are not generally significant for most uses. Consequently, for commercial and public use, only the three higher ratings of Low, Moderate and High (C, D and E) are used. http://www.bgs.ac.uk/products/geosure/pdf/soluble.pdf . These are the subdivisions that are also used on the interactive web GIS which explains these hazards and which can be accessed through http://www.bgs.ac.uk/britainbeneath/guide.html.

\section{Uses of the datasets}

\section{Insurance}

The national dissolution dataset is available commercially and has found uses in the insurance industry. Insurance companies have used it to define problematical areas where they wish to limit their exposure to risk or charge a slightly increase premium to reflect the increased claims that would occur in such areas. The availability of the GeoSure 
datasets enables the insurance industry to correlate their claims history with the likely geological causes.

\section{House purchase}

For the house buyer, the recent Government initiative to speed house sales transactions called for a "Homebuyers information pack" which was to include information derived from this dataset, however, the scheme has been cancelled. Third-party information providers and the British Geological Survey utilise the information and supply it to the public as part of their environmental information searches. The presence of a moderate or high dissolution rating (class E or D) does not mean that any particular property will collapse, but it acts as a warning that the area is susceptible to dissolution and may be prone to subsidence. The recommendation for house buyers in such areas is that a full structural survey is undertaken and that the surrounding properties and infrastructure are also examined for damage. If some evidence of subsidence is found in the immediate or surrounding area, further investigation is recommended.

\section{Urban and national planning and construction}

Local and National Government have a responsibility to protect the public from foreseeable hazards. Development on unstable ground is covered by the Planning Policy Guidance PPG 14 and its Annex 2 (Department of the Environment 1990, Department of Transport, Local Government and the Regions 2002). Local Government through their Local Development Plans have a responsibility to consider unstable ground in their local

areas. In some places, such as Ripon, they have had specific local advice (Thompson et al 1996, Paukstys et al 1997), which is now included in local planning policy, but for most of the country this has not been done. The national dissolution dataset and the detailed karst database provide the baseline information from which Local Government can obtain an assessment of the local stability of their area. 


\section{Linear route assessments - roads, pipelines, railways}

Linear structures such as railways, roads and large airfields are very susceptible to subsidence damage; even small amounts of settlement can be disastrous for fast moving rail traffic. Oil and gas pipelines are susceptible to subsidence movements, which can cause them to be run at lower and less economical pressures (Hucka et al 1986). The GeoSure dataset and the karst dataset allow the rapid assessment of new routes and the likely stability and risk to existing structures to be determined (Gibson et al 2005).

\section{Water abstraction and ingress}

The national karst dissolution dataset helps to define areas in gypsum karst where there is strong hydrogeological connectivity from the surface to the subsurface gypsum karst. This connectivity largely takes place down breccia pipes, collapsed areas and the bottoms of dolines. The connectivity through the sequence is important for aquifer modelling and aquifer protection. The karstic nature of the sequence and the active dissolution of gypsum explain why the Sherwood Sandstone, which is usually a very good aquifer, can contain significant amounts of sulphate-rich water at its western limit where it directly overlies mudstones that in turn overlie gypsum. Similarly, the dolomites of the Cadeby Formation may contain sulphate-rich water derived from the overlying gypsum in the Edlington Formation. The mudstones in the sequence do not act as an effective aquitard because they are perforated by breccia pipes caused by gypsum dissolution and this fact

must be considered when modelling the hydrogeology of the area. Areas of salt karst are not affected in the same way since the presence of brines makes them unattractive as aquifers. Water ingress also affects salt karst less as the salt at wet rock head may be protected in places by a layer of dense brine.

\section{Waste disposal sites}

Sinkholes in some places look like disused quarries and have in the past been used as waste disposal sites; east of Ripon, five holes were filled with domestic rubbish during 
the 1960's or early 70's. Because there is such good hydrogeological connectivity through the sinkholes and into the underlying breccia pipes to the aquifer, sinkhole areas should be avoided for waste disposal. Any leachate from these types of landfill can find its way very rapidly to the springs that drain the karstic system. Where landfill activities do have to take place consideration should be given to ascertaining the stability of the ground and to the provision of hydrological barriers and membranes. The karst database and the national dissolution dataset provide some background information for studies looking into the provision of waste disposal areas.

\section{Site specific enquiries and automated enquiries}

Both the site specific information contained in the karst database, and the national GeoSure dissolution dataset can be tailored to allow automated reporting for geological enquiries and studies. The British Geological Survey GeoReports http://shop.bgs.ac.uk/georeports/ utilise the GeoSure dissolution dataset to help provide background information for the BGS enquiry system, but, except for the basic Ground Stability Reports, the final interpretation and reporting is currently done manually even though many parts of the reports are automated. It is possible to subdivide the national dissolution dataset even further based on local geology and subsidence history. Paragraphs of locally specific text could then be attached to each polygon in the database. These paragraphs of information could then be automatically recalled to populate part of the local GeoReport. Further detail could also be added from the detailed karst database with information such as the distance from a sinkhole and the subsidence history of the sinkhole included. The generation of this type of automated reporting is the start of building an expert system for geological reporting.

\section{Conclusions}

The combination of digital map information and detailed karst database information has enabled the construction of a national dataset for the susceptibility of evaporite rocks (gypsum and salt) to dissolution problems. This dataset allied with the detailed karst 
dataset is a powerful tool for planning and hazard avoidance with the potential for automated geological reporting of the problems.

Acknowledgements. This work has benefited from discussions and help from numerous colleagues, especially Professor Martin Culshaw, Dr Francisco Gutierrez, Keith Adlam, Al Forster, Dr Andy Gibson, Dr Andy Farrant, Matt Harrison, Jenny Walsby, Rhonda Newsham and Kathrine Linley. The karst database has been largely populated by Dr Andy Farrant, Sarah Doran, Nathan Williams, Amanda Richardson and the author. Published with permission of the Director, British Geological Survey (NERC).

\section{References}

Applied Geology Limited (1993) Review of instability due to natural underground cavities in Great Britain. Royal Leamington Spa. Applied Geology Ltd.

Arup Geotechnics (1990) Review of mining instability in Great Britain, Stafford brine pumping. Volume 3/vi. Arup Geotechnics for the Department of the Environment.

Calvert AF (1915) Salt in Cheshire. Spon Ltd, London, 1206 p.

Collins JFN (1971) Salt: a policy for the control of salt extraction in Cheshire. Cheshire County Council.

Cooper AH (1986) Foundered strata and subsidence resulting from the dissolution of Permian gypsum in the Ripon and Bedale areas, North Yorkshire. In: Harwood, G M and Smith, D B (eds). The English Zechstein and related topics. Geological Society of London, Special Publication 22. pp 127-139

Cooper AH (1988) Subsidence resulting from the dissolution of Permian gypsum in the Ripon area; its relevance to mining and water abstraction. In: Bell FG, Culshaw MG, Cripps JC, Lovell MA (eds) Engineering Geology of Underground Movements. Geological Society of London, Engineering Geology Special Publication No 5, pp 387-390

Cooper AH 1989. Airborne multispectral scanning of subsidence caused by Permian gypsum dissolution at Ripon, North Yorkshire. Quarterly Journal of Engineering Geology (London), 22: 219-229.

Cooper AH (1998) Subsidence hazards caused by the dissolution of Permian gypsum in England: geology, investigation and remediation. In: Maund JG, Eddleston M (eds) Geohazards in Engineering Geology. Geological Society, London, Engineering Special Publications, 15, pp 265-275 
Cooper AH 2002. Halite karst geohazards (natural and man-made) in the United Kingdom. Environmental Geology. 42: 505-512.

Cooper AH, Calow R (1998) Avoiding gypsum geohazards: guidance for planning and construction. British Geological Survey Technical Report WC/98/5. Available on the Internet at: http://www.bgs.ac.uk/dfid-kar-geoscience/database/reports/colour/WC98005_COL.pdf

Cooper AH, Farrant AR, Adlam KAM, Walsby JC (2001) The development of a national geographic information system (GIS) for British karst geohazards and risk assessment. In: Beck BF, Herring JG (eds) Geotechnical and environmental applications of karst geology and hydrogeology. Proceedings of the eighth Multidisciplinary Conference on Sinkholes and the Engineering and Environmental Impacts of Karst, April 1-4 ${ }^{\text {th }}$ Louisville, Kentucky, USA. Balkema Publishers. pp 125-130

Cooper AH, Saunders JM (2002) Road and bridge construction across gypsum karst in England. Engineering Geology. 65: 217-223

Department of the Environment (1990) Planning policy guidance note 14: Development on unstable land. London, HMSO.

Department of Transport, Local Government and the Regions (2002) Planning policy guidance note 14. Development on unstable land. Annex2: Subsidence and planning. http://www.planning.detr.gov.uk/conindex.htm

Gibson AD, Forster A, Culshaw MG, Cooper AH, Farrant, AR, Jackson, N, Willet D (2006) Rapid Geohazard Assessment System for the UK Natural Gas Pipeline Network. Proceedings of the International Symposium on Geology and Linear Developments Geoline 2005. Lyon 23rd -25th May 2005. Digital Proceedings ISBN 2-7159-2982-x.

Griffin DA (1986) Geotechnical assesment of subsidence in and around Ripon, North Yorkshire, due to natural solution. Master Thesis. University of Newcastle upon Tyne, 85 pp. (Unpublished)

Gutierrez F, Cooper AH (2002) Evaporite dissolution subsidence in the historical city of Calatayud, Spain: damage appraisal, mitigation and prevention. Natural Hazards. 25: 259288

Hucka VJ, Blair CK, Kimball EP (1986) Mine subsidence effects on a pressurized natural gas pipeline. Mining Engineering. 38: 980-984.

Klimchouk A, Lowe D, Cooper A, Sauro, U. (eds) (1997) Gypsum karst of the world. International Journal of Speleology. 5 (3-4) for 1996, 307pp. 
Jones CJFP, Cooper AH (2005) Road construction over voids caused by active gypsum dissolution, with an example from Ripon, North Yorkshire, England. Environmental Geology. 48: 384-394

McNeary P (2000) The extent of subsidence caused by the dissolution of gypsum in Ripon, North Yorkshire. Unpublished BSc Thesis University of Leeds.

N.C.B. (1975) Subsidence Engineers’ Handbook. National Coal Board Mining Department. UK, 111 pp.

Paukštys B, Cooper AH, Arustiene J (1997) Planning for gypsum geohazards in Lithuania and England. In: Beck FB, Stephenson JB (eds) The Engineering Geology and Hydrogeology of Karst Terranes. Proceedings of the Sixth Multidisciplinary Conference on Sinkholes and the Engineering and Environmental Impacts of Karst Springfield/Missouri/69 April 1997 AABalkema, Rotterdam. pp 127-135

Ryder PF, Cooper AH (1993) A cave system in Permian gypsum at Houtsay Quarry, Newbiggin, Cumbria, England. Cave Science. 20: 23-28.

Seedhouse RL, Sanders RL (1993) Investigations for cooling tower foundations in Mercia Mudstone at Ratcliffe-on-Soar, Nottinghamshire. In: Cripps JC, Coulthard JC, Culshaw MG, Forster, A, Hencher SR, Moon C. (eds) The Engineering Geology of Weak Rock. Proceedings of the 26th annual conference of the Engineering Group of the Geological Society, Leeds, September, 1990. AA Balkema, Rotterdam. pp 465-471

Thomson A, Hine PD, Greig JR, Peach DW (1996) Assessment of subsidence arising from gypsum dissolution: Technical Report for the Department of the Environment. Symonds Group Ltd, East Grinstead, 228 pp

West, IM (1964) Evaporite diagenesis in the Lower Purbeck Beds of Dorset. Proceedings of the Yorkshire Geological Society, 34: 315-330. 